УДК 343.2

https://doi.org/10.34142/23121661.2020.32.11

orcid.org/0000-0003-0090-5005

(c) Єна I.O., 2020

\author{
I.O. Єна
}

ПРАВОВА РЕГЛАМЕНТАЦІЯ ЗЛОЧИНІВ ПРОТИ ОСНОВ НАЦІОНАЛЬНОЇ БЕЗПЕКИ (ДЕРЖАВИ) ТА ПОКАРАНЬ ЗА ЇХНЄ ВЧИНЕННЯ В ПЕРШ РОКИ РАДЯНСЬКОЇ ВЛАДИ

\title{
I. Yena
}

\section{LEGAL REGULATION OF CRIMES \\ AGAINST BASES OF NATIONAL SAFETY OF GOVERNMENT AND PUNISHMENTS FOR THEIR FEASANCE IN THE FIRST YEARS OF SOVIET POWER}

\begin{abstract}
Анотація. Метою статті $є$ проведення історико-правового аналізу порядку правового регулювання злочинів та покарань проти основ національної безпеки (держави) з моменту становлення радянської влади і в перші роки розвитку радянської правової системи.

Ключові слова: злочин, покарання, призначення покарання, національна безпека, злочини проти держави.
\end{abstract}

Аннотация. Целью статьи является проведение историко-правового анализа порядка правового регулирования преступлений и наказаний против основ национальной безопасности (государства) с момента становления советской власти и в первые годы развития советской правовой системы.

Ключевые слова: преступление, наказание, назначение наказания, национальная безопасность, преступления против государства.

Annotation. The aim of the article is realization of історико-правового analysis of order of the legal adjusting of crimes and punishments against bases of national safety (states) from the moment of becoming of soviet power and in the first years of development of the soviet legal system. It is suggested to divide the soviet stage of development of criminal legislation in relation to crimes against bases of national safety (states) on two stages: the becoming stage and stage of development. In the article the dramatic change of direction of development of legislation of this family is determined toward the increase of repressiveness during establishment of power of advices on territory of modern Ukraine and her further functioning. Established, that such change was caused by the necessity of maintenance of power by the representatives of new ruling elite and actually repressive and punitive orientation of new power, that wished to save the new universe and by attempts to identify itself with the state. For this period in the structure of legislation new crimes 
and punishments that were not characteristic to the past period of development of legislation appeared about criminal responsibility. Drawn conclusion, that the investigated period was characterized most криміналізацією of acts against the state, political system for all the time of development of legislation about criminal responsibility on territory of Ukraine.

Keywords: crime, punishment, awarding punishment, national safety, crimes against the state.

Постановка проблеми. У процесі побудови в Україні демократичної, соціальної та правової держави особливого значення набуває глибоке вивчення, а часом і переосмислення багатьох історичних моментів [9, с. 80]. Дослідження історії розвитку національного законодавства має велике значення для кожного дослідника в галузі права, будь-яка наукова розвідка належної якості неможлива без узагальнення та оцінки досвіду науковців-попередників [3, c. 55]. Рішення нагальних проблем, пов'язаних із реформуванням чинного законодавства про кримінальну відповідальність і правової системи української держави загалом, значною мірою залежить від наукового аналізу історичного досвіду й використання його результатів у законотворчих процесах сьогодення [8, с. 106]. Усі вищенаведені тези підтверджують аксіому - застосування історико-правового методу є доречним і обов'язковим. Не є винятком i необхідність дослідження історичних етапів розвитку законодавства, що регулювало призначення покарання за злочини проти основ національної безпеки (або держави). Предметом запропонованої наукової статті $\epsilon$ аналіз законодавства радянської епохи, яке унормовувало власне злочини та призначення покарання за злочини такого роду. На сторінках наших наукових досліджень пропонуємо розділити радянський етап розвитку законодавства про призначення покарання за злочини проти основ національної безпеки (держави) на два етапи: 1-ий етап - становлення радянського законодавства до моменту відлиги (до 1953); 2-ий етап - розвиток радянського законодавства (до 1991 р.).

У цій науковій статті пропонується розглянути перший етап розвитку радянського законодавства щодо правової регламентації злочинів та призначення покарання за злочини проти основ національної безпеки (держави).

Аналіз останніх досліджень. Традиційно питанням дослідження порядку призначення покарання займалися вчені-пенологи протягом усього періоду розвитку законодавства про кримінальну відповідальність. Так, серед науковців, які досліджували призначення покарання за злочини проти основ національної безпеки, зокрема й протягом радянського періоду, можна назвати О.Ф. Бантишева, С.В. Дьякова, Ю.В. Луценка, В.М. Трубникова, О.В. Шамара, Ю.В. Шинкарьова. Але, незважаючи на дослідження згаданими вченими окремих аспектів призначення покарання, зокрема й за злочини проти основ національної безпеки, особливості призначення покарання за злочини такого роду в перші роки існування радянської держави не розглядалися. Так, і серед науковців, які досліджували різноманітні склади злочинів у цій групі, порядок призначення покарання за їхнє вчинення залишився майже поза увагою. 
Метою запропонованої статті є проведення історико-правового аналізу законодавства, що регламентувало кримінальну відповідальність за злочини проти основ національної безпеки (держави) в період з 1917 р. до часу «відлиги» 1953 р., який характеризувався зменшенням репресивності законодавства в цьому напрямі.

Незважаючи на те, що власне радянська держава була створена на початку 20-х рр. минулого століття, пропонуємо проводити аналіз із моменту повалення царської влади на території України та поглинання частини, а згодом і майже всієї України комуністичною владою.

Особливо бурхливими щодо реформи законодавства, яке охороняло підвалини національної безпеки та державності, стали перші роки після комуністичного заколоту. Як вказує С.В. Дьяков, на першому етапі після революції тимчасові закони відображали загострення класової боротьби, прагнення всіма силами, зокрема правовими, придушити політичного супротивника [2, с. 13].

Саме тому після насильницької зміни влади та жовтневих подій 1917 р., держава в особі іiі нових «керівників» насамперед турбувалася за власну безпеку та розширення меж свого впливу. Показником цього, поряд із змінами у низовій ланці «управлінців» - виникнення політичних лідерів та ватажків робітничо-селянського руху, було прийняття великої кількості нормативних актів - декретів, що в той час були як тимчасовими законами, так і заміняли підзаконні акти. Окремими декретами Ради народних комісарів (далі - РНК) та постановами Всеукраїнського центрального виконавчого комітету (далі ВУЦВК) фактично встановлювалися підстави визначення злочинності та караності діянь, зокрема й тих, що посягали на «новонароджену» радянську владу. Декрет стає директивою, інструкцією для практичної діяльності; широка революційна правотворчість має конкретизувати, наповнювати практичним змістом, здійснювати на практиці заходи радянської влади [4, с. 55].

Для формування основних засад та фундаменту нового уряду, його підтримки з боку агресивно налаштованих до попереднього режиму громадян, насамперед серед його активних представників - військових, Декретом II Всеросійського 3'їзду Рад «Про відміну смертної кари» від 26 жовтня 1917 р., офіцерів-революціонерів, які були під арештом за «політичні злочини», необхідно було звільнити негайно [7, с. 9]. Застосування смертної кари було призупинено лише до початку 1918 р., адже вже 21 лютого 1918 р., у зв'язку з розпочатим 18 лютого 1918 р. німецьким наступом, РНК приймає Декрет «Соціалістична вітчизна в небезпеці!», відповідно до п. 8 якого «ворожі агенти, спекулянти, громили, хулігани, контрреволюційні агітатори, німецькі шпигуни розстрілюються на місці злочину» [1, с. 491].

Не менш важливе значення для боротьби 3 контрреволюційними проявами мали Декрет РНК «Про суд» від 24 листопада 1917 р., який у п. 8 визначив, що для боротьби 3 контрреволюційними силами у вигляді заходів, що застосовуються для охорони від них революції та ії завоювань, а так само для вирішення справ щодо боротьби 3 мародерством i розкраданнями, 
саботажем та іншими зловживаннями торговців, промисловців, чиновників та інших осіб, засновуються робітничі й селянські революційні трибунали в складі одного голови і шести чергових засідателів, які обираються губернськими або міськими Радами робітничих, солдатських і селянських депутатів [7, с. 16], та звернення РНК до всього населення «Про боротьбу з контрреволюційним повстанням Каледіна, Корнілова, Дутова, що підтримувалося Центральною Радою» від 26 листопада 1917 р., у п. 4 якого зазначалося, що «будь-яке сприяння контрреволюціонерам з боку заколотного населення або залізничного персоналу буде каратися за всією суворістю революційних законів» [7, с. 17].

Отже, будь-які посягання на радянську («робітничо-селянську») владу в цей час сформували комплекс так званих «контрреволюційних злочинів» (на той час цього поняття в законодавстві закріплено не було), що мали найвищий ступінь суспільної небезпеки. Як зазначає Ю.В. Луценко, загальне поняття контрреволюційних злочинів, виокремлення конкретних їхніх видів розвивалося в процесі здійснення радянськими каральними органами боротьби 3 контрреволюцією [6, с. 14]. Відслідковуючи історичну послідовність розвитку поняття контрреволюційних злочинів, він указує на такі етапи їхнього виникнення:

1) поняття контрреволюційного повстання, заколоту, саботажу (листопадгрудень 1917 р.);

2) поняття контрреволюційної агітації та пропаганди (грудень 1917 р.);

3) поняття державної зради та шпигунства (травень-червень 1918 р.);

4) поняття терористичного акту (вересень 1918 р.);

5) поняття диверсійного акту (червень 1919 р.) [6, с. 14].

Не ставлячи під сумнів зроблені автором висновки хочемо наголосити, що вказані діяння (посягання на революцію та іiі завоювання) фактично ще не були сформульовані як злочини в кримінально-правовому їхньому значенні, не мали конкретних ознак складу, а були лише формою реагування держави на внутрішні та (або) зовнішні загрози.

Наступним етапом у формуванні законодавчого (нормативного) визначення контрреволюційних злочинів є прийняття постанови РНК «Про красний терор» від 5 вересня 1918 р., відповідно до якої було закликано «...захистити Радянську Республіку від класових ворогів шляхом ізолювання їх у концентраційних таборах; що підлягають розстрілу всі особи, причетні до білогвардійських організацій, змов і заколотів; що необхідно опублікувати імена всіх розстріляних, а також підстави застосування до них цього заходу» [7, с. 34]. У вказаній постанові (яка має на той час характер керівної настанови) чітко визначено, які покарання застосовуються до осіб винних у 1) сприянні діяльності антирадянських (білогвардійських) організацій, 2) учиненні змови та заколоту - державній зраді - розстріл (який у подальшому, до речі, було закріплено як вид покарання п. ст. 25 Керівних засад з кримінального права РСФСР від 12 грудня 1919 р.). 
Більш-менш повне уявлення про систему контрреволюційних посягань можна сформувати, проаналізувавши постанову Касаційного відділу ВЦВК «Про підсудність революційних трибуналів» від 6 жовтня 1918 р., відповідно до якої трибуналу підсудні справи щодо звинувачення: у контрреволюційній діяльності, саботажі, дискредитації влади, шпигунстві [7, с. 35-37].

Як зазначають укладачі монографії з історії радянського кримінального права, наприкінці періоду громадянської війни соціалістичне кримінальне законодавство мало, по суті, закінчену систему норм про контрреволюційні злочини:

1) контрреволюційні повстання і заколот;

2) привласнення функцій державної влади з контрреволюційною метою;

3) державна зрада і шпигунство;

4) шкідництво й саботаж;

5) диверсійний акт;

6) контрреволюційна агітація та пропаганда;

7) політичне хуліганство;

8) участь у контрреволюційних організаціях;

9) активна боротьба з революційним рухом за часів царського ладу [4, с. 194].

301 червня 1922 р. набуває чинності перший радянський Кримінальний кодекс (КК РРФСР), який об'єднав у собі кримінально-правові норми про відповідальність за посягання на найбільш важливі об'єкти для радянської влади. Як зазначають О.Ф. Бантишев та О.В. Шамара, майже за п’ять років до прийняття КК каральні органи «першої у світі держави робітників і селян» керувалися у своїй діяльності декретами (здебільшого надзвичайними) й революційною правосвідомістю [5, с. 15].

КК 1922 р. містив Розділ I Особливої частини 3 назвою Державні злочини, у якій структурно було виділено норми «1. Про контрреволюційні злочини» (статті 57-73) та норми «2. Про злочини проти порядку управління» (статті 74-104). Розглянемо лише ті суспільно небезпечні діяння, що кодексом було визнано контрреволюційними злочинами.

У ст. 57 КК 1922 р. було сформульовано поняття контрреволюційного злочину - будь-яка дія, спрямована на повалення завойованої пролетарською революцією влади робітничо-селянських рад та чинного на підставі Конституції СРСР Робітничо-Селянського Уряду, а також дії, мета яких - надання допомоги тій частині міжнародної буржуазії, що не визнає рівноправності влади, яка прийшла на зміну капіталізму, комуністичної системи власності й прагне до іï повалення шляхом інтервенції чи блокади, шпигунства, фінансування преси й тому подібними засобами [7, с. 123].

Відповідно до цього КК, систему контрреволюційних злочинів утворювали злочини, які можна безпосередньо вважати контрреволюційними, та злочини, що сприяли контрреволюційній діяльності (агітація, пропаганда, заклики тощо). 
«Безпосередніми» контрреволюційними злочинами визнані такі:

- організація в контрреволюційних цілях збройних повстань; вторгнення на радянську територію збройних загонів або банд; участь у будь-якій спробі в тих самих цілях захопити владу в центрі і на місцях; насильницьке відторгнення від країни будь-якої іiі частини; розірвання укладених нею договорів (ст. 58);

- зносини з іноземними державами або їхніми окремими представниками 3 метою схиляння їх до збройного втручання в справи країни; оголошення війни або організація військової експедиції; сприяння іноземним державам уже після оголошення їм війни або організація експедиції, у чому б це сприяння не полягало (ст. 59);

- участь в організації, що діє 3 метою вчинення злочинів, зазначених у ст.ст. 57-59 (ст. 60);

- участь в організації або сприяння організації, що діє для допомоги міжнародної буржуазії, зазначеної у ст. 57 (ст. 61);

- участь в організації, що діє 3 метою, зазначеною у ст. 57, шляхом збудження населення до масових заворушень, відмови від сплати податків і невиконання повинностей або всяким іншим шляхом із завданням збитку диктатурі робітничого класу і пролетарської революції, якщо навіть збройне повстання або збройне вторгнення і не було найближчим завданням діяльності цієї організації (ст. 62);

- участь в організації, яка протидіє у контрреволюційних цілях нормальній діяльності радянських установ або підприємств чи використовує такі в тих самих цілях (ст. 63);

- участь у виконанні з контрреволюційною метою терористичних актів, спрямованих проти представників радянської влади або діячів революційних робітничо-селянських організацій, якщо навіть окремий учасник такого акту й не належав до контрреволюційної організації (ст. 64);

- організація в контрреволюційних цілях знищення або пошкодження вибухом, підпалом чи іншим способом залізничних чи інших шляхів і засобів сполучення, засобів народного зв’язку, водопроводів, громадських складів та інших споруд або будівель, а так само участь у вивиконанні зазначених злочинів (ст. 65);

- участь у шпигунстві всякого роду, що виражається у передачі, повідомленні, або викраденні, або збиранні відомостей, що мають характер державної таємниці, особливо військових, іноземним державам або контрреволюційним організаціям у контрреволюційних цілях або за винагороду (ч. 1 ст. 66);

- активні дії та активна боротьба проти робітничого класу й революційного руху, проявлені на відповідальних посадах за часів царського ладу (ст. 67).

За вказані діяння, за наявності обізнаності винного про кінцеву мету контрреволюційну діяльність, були передбачені покарання, що визначалися ч. 1 ст. 58 КК, а саме - вища міра покарання (відповідно до ст. 33 цього ж 
Кодексу - розстріл) з конфіскацією всього майна, а в разі вчинення злочину за пом'якшувальних обставин допускається зменшення покарання до позбавлення волі на строк, не нижчий ніж п'ять років із суворою ізоляцією і конфіскацією всього майна.

Якщо судом буде встановлено необізнаність учасників про кінцеві цілі зазначених злочинів, їхнє вчинення карається позбавленням волі на строк, не нижчий ніж три роки (ч. 2 ст. 58 КК). Таке саме покарання може бути призначено за оголошення відомостей, про які йдеться в ч. 1 ст. 66 КК (відомості, що мають характер державної таємниці), за відсутності контрреволюційних або корисливих цілей і необізнаності про можливі наслідки такої (ч. 2 ст. 66).

За злочини, що сприяли контрреволюційній діяльності, було передбачено менш суворе покарання, але пов'язане, як правило, з ізоляцією від суспільства, вигнанням чи примусовими роботами.

Так, приховування і пособництво всякого роду злочинам, передбаченим ст.ст. 57-67, не пов'язаним із безпосереднім їхнім учиненням або в разі необізнаності про їхні кінцеві цілі, каралося позбавленням волі на строк, не нижчий ніж один рік (ст. 68).

Пропаганда й агітація, що полягала в закликах до повалення влади Рад шляхом насильницьких або зрадницьких дій, або шляхом активної чи масивної протидії Робітничо-Селянському уряду, або масового невиконання покладених на громадян військової чи податкової повинностей, каралися позбавленням волі на строк, не менший ніж три роки із суворою ізоляцією.

За ті самі злочини, учинені у військовій обстановці або під час народних заворушень, покарання підвищується до вищої міри покарання.

Заклик до невиконання або протидії розпорядженням центральної або місцевої влади за умови невстановлення контрреволюційних цілей, карався покаранням у вигляді позбавлення волі на строк, не нижчий ніж один рік із суворою ізоляцією (ст. 69).

Пропаганда й агітація 3 метою допомоги міжнародній буржуазії, зазначеної у ст. 57, каралися вигнанням за межі країни або позбавленням волі на строк, не нижчий ніж три роки (ст. 70).

Самовільне повернення в межі країни в разі застосування покарання у вигляді вигнанням за межі країни, карається вищою мірою покарання (ст. 71).

Виготовлення, зберігання 3 метою розповсюдження i поширення агітаційної літератури контрреволюційного характеру караються позбавленням волі на строк, не нижчий ніж один рік (ст. 72).

Вигадки й поширення 3 контрреволюційною метою неправдивих чуток або неперевірених відомостей, що можуть викликати суспільну паніку, порушити недовіру до влади або дискредитувати їі, караються позбавленням волі на строк, не нижчий ніж шість місяців.

У випадку недоведеності контрреволюційності зазначених дій покарання може бути знижене до трьох місяців примусових робіт (ст. 73) [7, с. 123-124]. 
Висновки з иъього дослідження і перспективи подальших розвідок у изьому напрямі. На підставі аналізу законодавства перших років становлення і розвитку радянської влади на землях сучасної України, можна зробити декілька висновків.

1. Перший період розвитку законодавства щодо охорони державності в досліджувані роки характеризувався необхідністю захисту здобутків революції від контрреволюційних течій та різноманітних визвольних рухів, сутність яких суперечила комуністичній експансії.

2. У зв'язку із «новою реальністю» і появою «комуністичної свідомості» перелік злочинів, існування яких було покликано забезпечити охорону державності (комуністичної влади), значно збільшився.

3. Покарання, що передбачалися за вчинення злочинів проти держави та комуністичної влади, вражали своєю суворістю.

4. Перші роки комуністичного панування характеризувалися відсутністю сталого систематизованого й кодифікованого кримінального законодавства, що призводило до видання актів, які мали були в «пожежному» порядку гасити спротив радянській владі.

5. I останнє, аналіз попередніх етапів розвитку законодавства щодо правового регулювання злочинів та покарань за посягання на національну безпеку (державу), так і аналіз наступних періодів довели, що вивчений етап вважається найрепресивнішим порівняно з усіма іншими.

Але існує впевненість, що сучасне законодавство прогресує у правильному векторі й забезпечує охорону національної безпеки країни не як самоціль, а як дієвий засіб забезпечення конституційних цінностей у країні.

\section{Література}

1. Декреты Советской власти. Т. 1. Москва, Гос. изд-во полит. литературы, 1957. 626 с; 2. Дьяков С.В. Преступления против основ конституционного строя и безопасности государства: уголовно-правовое и криминологическое исследование. Изд. 2-е, испр. и доп. Санкт-Петербург: Юридический центр-Пресс, 2012. 267 с. 3.Срєгян А.Р. Формування системи покарань в Київській Русі: аналіз основних джерел права IX-XII ст. Часопис Київського університету права. 2010. № 4. С. 55-58; 4. История советского уголовного права / А.А. Герцензон и др. Москва: Юрид. изд-во МЮ СССР, 1948. 466 с. 5. Кримінальна відповідальність за злочини проти основ національної безпеки України (проблеми кваліфікації): монографія / О.Ф. Бантишев, О.В. Шамара. Вид. 3-є, перероб. та доп. Луганськ: Віртуальна реальність, 2014. 240 с. 6. Луценко Ю. В. Звільнення від кримінальної відповідальності за злочини проти основ національної безпеки України: монографія. Харків: Право, 2015. 200 с. 7. Сборник документов по истории уголовного законодательства СССР и РСФСР: 1917-1952 гг. / под ред. И.Т. Голякова. Москва: Гос. издательство юрид. лит., 1953. 464 с. 8. Шинкарьов Ю.В. Спеціальні засади призначення покарання в руській правді. 36. наук. пращь Харківськ. наи. пед. ун-ту імені Г.С. Сковороди. Сер. «Право». Харків: Наук. видання. Вип. 28. 2018. С. 106-114; 8. Шинкарьов Ю.В. Спеціальні засади призначення покарання за Литовськими статутами. 3б. наук. пращь Харківськ. нац. пед. ун-ту імені Г.С. Сковороди. Сер. «Право». Харків: Наук. видання. Вип. 29. 2019. С. 80-86. 